\title{
ALLOWING FOR HETEROGENEITY IN MONETARY SUBJECTIVE WELL-BEING VALUATIONS
}

\author{
Emmanouil Mentzakis* \\ Department of Economics, McMaster University, 1280 Main St. West, Hamilton, Ontario, L8S 4M4, \\ Canada
}

\section{SUMMARY}

Recent research on 'happiness' equations has placed monetary values on many life events (e.g. health problems, marriage, death of spouse etc.). Potentially, such work has practical implications for policy-makers and the courts. This article argues that the choice of statistical method requires caution. Accounting for heterogeneity through less restrictive models it argues that the commonly used standard linear or ordered response models seem to consistently overstate valuations. New monetary estimates for a number of health problems, social capital indicators, marital status changes and social relationships are obtained for the UK. However, increased flexibility in valuations comes at an interpretational cost.

JEL classification: C25, D65

KEY WORDS: Generalized ordered response models; compensating variation; monetary valuations; subjective well-being

\section{INTRODUCTION}

A growing body of literature in economics is concerned with what is being referred to as happiness economics, where subjective well-being ${ }^{1}$ (SWB) equations are estimated as a function

\footnotetext{
* Correspondence to: Department of Economics, McMaster University, 1280 Main St. West, Hamilton, Ontario, L8S 4M4, Canada. E-mail: mentzak@mcmaster.ca
} 
of a number of socio-demographic characteristics and other variables of interest (Winkelmann and Winkelmann, 1998; Di Tella et al., 2001; Frey and Stutzer, 2002; Di Tella and MacCulloch, 2006; Clark et al., 2008; Smith, 2008). Much of the discussion on the topic originates from the so-called 'Easterlin Paradox', which posits that within a country, at a given time, those with higher incomes are on average happier, while over time, despite increases in income, average levels of happiness have not increased significantly (Easterlin, 1974; Easterlin, 1995; Easterlin, 2001).

The use of such SWB equations has, additionally facilitated the application of the compensating variation $(\mathrm{CV})$ method to value various commodities/activities/situations that lack an explicit market (Clark and Oswald, 2002; van Praag and Baarsma, 2005; Welsch, 2006; Powdthavee, 2008). Valuation is achieved through implied trade-offs between income and the variable of interest. Compared to stated preference techniques, compensating variation avoids the associated hypothetical bias $^{2}$, while the general and vague formulation of SWB questions and their vulnerable nature (potentially affected by context, mood etc.) might be a cause of concern (Smith, 2008), although not grounds to dismiss the method altogether (Kahneman and Krueger, 2006). The ability to provide monetary valuations through market data and avoid hypothetical valuation questions makes this relatively new method attractive for the valuation of subtle human conditions (e.g. health problems) or situations of sensitive nature (e.g. bereavement from the loss of a loved one) faced in economic evaluations and other policy contexts (Dolan and Peasgood, 2008). The argument becomes even more appealing when calculation of compensatory damages is brought forward (Oswald and Powdthavee, 2008), although it is acknowledged that it might be a while before such method (or mixture of methods) is used in courts.

Clark and Oswald (2002) used the method to calculate the values of various life events (e.g. illness, marriage, or unemployment), Frey et al. (2004) calculated the trade-off between terrorism and income, Van Praag and Baarsma (2005) assessed the monetary value of the noise

\footnotetext{
${ }^{1}$ The latent SWB is typically measured as a categorical variable derived directly from questions such as: "How dissatisfied or satisfied are you with your life overall", with a number of possible outcomes ranging from 'not satisfied' to 'completely satisfied'.

${ }^{2}$ Hypothetical bias is a common criticism for stated preferences techniques (i.e. contingent valuation and choice experiments) and refers to situations where individuals' stated values or preferences differ from their actual ones (Bateman et al., 2002).
} 
damage caused by aircrafts, Welsch (2006) obtained value estimates for air pollution, while Powdthavee (2008) placed monetary values on interaction with friends, relatives, and neighbours. Similar attempts have been made in health with Ferrer-i-Carbonell and Praag (2002) estimating values for chronic diseases and other conditions, Groot and Van den Brink (2004) focusing on severe headache and migraine and Groot and Van den Brink (2006) on cardiovascular diseases.

Furthermore, recent research in the SWB literature has shown heterogeneity to be present within the SWB scales. Huppert and Whittington (2003) observe a degree of independence in the determinants of positive and negative well-being, indicating that ill-being and well-being are two distinct dimensions and not opposite ends of the same scale (p.S24, Headey and Wooden, 2004). Other studies exploring how income affects happiness among different groups within samples suggest that the slope of the happiness-income relationship might vary (Frijters et al., 2004; Lelkes, 2006). Clark et al. (2005) investigate slope heterogeneity using latent classes, Boes and Winkelmann (2006a) allow the coefficient of income to vary across response categories, while Mentzakis and Moro (2009) further allow heterogeneity across both income and SWB classes. Considering these findings and the latent nature of the happiness scales, questions regarding the monetary valuations obtained from the estimation techniques used to commonly model SWB equations arise.

This paper brings together both strands of the literature and obtains monetary estimates for a number of health problems and social capital indicators. Additionally, it revisits monetary values for marital status changes and social relationships previously obtained in the literature for the UK. Accounting for heterogeneity of effects through generalized ordered response models, it demonstrates that, despite their attractiveness, the commonly used linear and standard ordered response models provide monetary valuations that are consistently higher and should be treated with caution. Generalized models avoid the cardinal interpretation of the scales present in linear models and relax assumptions imposed in standard ordered response models making them more suitable for SWB analysis. Section 2 describes the data and Section 3 presents the econometric model and monetary valuation calculations. Results and their discussion are given in Section 4 and 5, while Section 6 concludes.

\section{DATA}


For this study data from the British household Panel Survey (BHPS) are used. The BHPS is an annual longitudinal survey carried out by the ESRC UK Longitudinal Studies Centre with the Institute for Social and Economic Research at the University of Essex. More than 5000 households, with approximately 10,000 individual are sampled per wave. Due to fact that some of the variables appear only on a subsample of waves, analysis is restricted to adults from waves $8,10,12$ and 14 .

Subjective well-being is derived from the question, "How dissatisfied or satisfied are you with your life overall", with 7 possible outcomes ranging from "not satisfied at all" to "completely satisfied", where, due to low incidence rates, the first two outcomes are aggregated (Table 1). As an indicator of income, monthly equivalised household income is used (Alesina $e t$ al., 2004; Blanchflower and Oswald, 2004). For the equivalisation we employ the McClements (1977) equivalisation scale provided in the data. Other variables used in the analysis were age and age squared of the individual, gender, household size, number and age of kids, marital status, employment status, education, binary indicators for the presence of health problems (Groot, 2000) and social capital (Powdthavee, 2008), a number of neighborhood specific indicators (i.e. noise from neighbours, street noise, pollution/environmental problems and vandalism or crime) and a set of regional and time dummies to account for unknown geographical and time patterns or events (Frey and Stutzer, 2002; Ferrer-i-Carbonell and Frijters, 2004). Definitions and descriptive statistics for the regressors are given in Table 2.

\section{ECONOMETRIC MODEL AND ESTIMATION}

Using the ordinal nature of the SWB variable and assuming SWB to be a linear function of the regressors, the random effects ordered response models is

$$
\begin{aligned}
& y_{i t}^{*}=\beta x_{i t}+\mu_{i}+\varepsilon_{i t} \\
& y_{i t}=j \text { if } \quad \xi_{\mathrm{j}-1}<y_{i t}^{*} \leq \xi_{j}, \quad \text { for } j=1, \ldots, J
\end{aligned}
$$


where $i=1, \ldots, n$ and $t=1, \ldots, T$ denote individuals and time, respectively. $y_{i t}^{*}$ is the latent process of happiness linked to the observed outcome $y_{i t}$, through the SWB question. The vector $x_{i t}$ indicates the regressors used in the estimation, while $\xi_{j}$ are the cut-off points to be estimated along with the rest of the parameters. $\mu_{i}$ is the time invariant, individual-specific random component. $\varepsilon_{i t}$ is the time and individual specific error term, capturing the unobserved heterogeneity, assumed to be normally distributed and uncorrelated with $x_{i t}$ and $\mu_{i}$ and across individuals (something relaxed later on), but possibly serially correlated. Conditioning on $\mu_{i}$, the ordered probit model is

$$
\operatorname{Pr}\left(y_{i t}=j \mid x_{i t}, \mu_{i}\right)=\Phi\left(\xi_{\mathrm{j}}-\beta x_{i t}-\mu_{i}\right)-\Phi\left(\xi_{j-1}-\beta x_{i t}-\mu_{i}\right)
$$

where $\xi_{0}=-\infty$ and $\xi_{J}=\infty$ with $\Phi\left(\xi_{0}\right)=0$ and $\Phi\left(\xi_{J}\right)=1$, while $\Phi$ denotes the standard normal cumulative function where without loss of generality the variance is equal to 1 .

However, the model presented above has a fundamental limitation referred to as the single crossing property (or parallel lines assumption). As we move from the probability of the smallest outcome to the probability of the largest outcome, the marginal probability effects are allowed to change their sign (effect) only once (Maddala, 1983; Boes and Winkelmann, 2006b). Stated differently, the ordered response model is equivalent to $\mathrm{j}-1$ binary regressions, assuming that the coefficients' slopes are constant across regressions, implying a homogenous effect of the variables across the SWB distribution (Long and Freese, 2005). Log-likelihood ratio tests (Long and Freese, 2005) can indicate rejection or not of this assumption. Relaxation of the assumption can be carried out by making the cut-off points linear functions of the regressors (Terza, 1985), and as such introduce heterogeneity in the coefficients. Substituting $\xi_{i j}=k_{j}+\gamma_{j} x_{i t}$ in eq. 3 gives the generalized model,

$$
\operatorname{Pr}\left(y_{i t}=j \mid x_{i t}, \mu_{i j}\right)=\Phi\left(\kappa_{j}-\beta_{j} x_{i t}-\mu_{i j}\right)-\Phi\left(\kappa_{j-1}-\beta_{j} x_{i t}-\mu_{i j}\right)
$$

where the estimated coefficients are $\beta_{j}=\beta-\gamma_{j}$. 
As before, $\beta_{j}$ and $\kappa_{j}$ are the parameters to be estimated, while following Mundlak (1978) and Chamberlain (1982) we further relax the assumption of no-correlation between $\mu_{i}$ and $x_{i t}$ by parameterizing the individual effect

$$
\mu_{i j}=+\mu_{j} \bar{x}_{i}+v_{i}
$$

For standard, as well as, generalized ordered probit models, CV values following estimation are obtained by taking the negative of the ratio of the marginal effect of the variable of interest to the marginal effect of income ${ }^{3}$. Marginal effects indicate the change in the probability of belonging in a certain SWB category for a change in a variable of interest. Hence, the obtained $\mathrm{CV}$ ratio is the amount of money required to compensate an individual so that they stay at the same SWB level following a change in his/her situation. When the variable of interest is continuous (income is also continuous) and due to the way the marginal effects (at the mean) are calculated, the $\mathrm{CV}$ ratio is equal to the ratio of the estimated coefficients. However, it is important to note that when $\mathrm{CV}$ values of binary indicators are required, such simplification is not applicable and the ratio of the marginal effects has to be taken ${ }^{4}$. Nevertheless, this distinction is not always clear in the literature making comparison of monetary valuations across studies difficult (Powdthavee, 2008) $)^{5}$. For completeness, fixed effects panel linear models are additionally estimated and presented.

\section{RESULTS}

\footnotetext{
${ }^{3}$ Note that in linear models the estimated coefficients represent marginal effects and as such their ratios give the corresponding $\mathrm{CV}$ values.

${ }^{4} \mathrm{We}$ are interested in discrete probability effects computed for a change in situation, while holding all else to their means: $\Delta \operatorname{Pr}\left(y_{i t}=j \mid \bar{x}_{i t}, \bar{\mu}_{i j}\right) / \Delta z_{k}=\operatorname{Pr}\left(y_{i t}=j \mid \bar{x}_{i t}, \bar{\mu}_{i j}, z_{k}=1\right)-\operatorname{Pr}\left(y_{i t}=j \mid \bar{x}_{i t}, \bar{\mu}_{i j}, z_{k}=0\right)$.

${ }^{5}$ The coefficients in ordered response models are arbitrarily scaled and hence lack clear interpretation. Taking the ratios of coefficients gets rid of the scale problems, but the interpretation of the ratio is given in terms of the latent variable.
} 
Sample descriptive statistics are presented in Table 2, with the regressors' reference categories given in parentheses. Valuations will focus on the numbered variables (1 to 8$)$ in Table $2^{6}$. Turning to Table 3, monetary values from the ordered probit model are given along with the corresponding values from a fixed effects linear model, revealing closely comparable figures. The last 3 columns of Table 3 give the averages of all the significant $\mathrm{CV}$ ratios of the ordered model, their standard deviations and the size of the deviation relative to the average, respectively. The small values is last column throughout the table (with a mean of less than $7 \%$ and with less than $10 \%$ in all but 5 variables) is an indication of the consistency of values across SWB levels (for the ordered model) for each variable. When changes described by the variables indicate a worsening of the situation relative to the reference state, individuals require an increase in income to compensate for their loss of utility (i.e. a positive sign for the ratio) and vice versa ${ }^{7}$. For example, in order for someone to remain to their respective happiness level following a problem in their "Arms, legs, hands, etc." they would require from $£ 9,015$ to $£ 9,497$ per month ${ }^{8}$ depending on their starting happiness level, with an average of about $£ 9,200 \mathrm{pm}$. Similarly, from the linear model the corresponding value is $£ 9,265 \mathrm{pm}$. Focusing on the average values, hearing problems are valued at $£ 6,717 \mathrm{pm}$, with a similar value for heart and blood pressure problems $(£ 6,564 \mathrm{pm}) . \mathrm{CV}$ values for stomach/digestion problems and anxiety/depression are around $£ 8,163 \mathrm{pm}$ and $£ 41,967 \mathrm{pm}$, respectively, while getting separated, divorced or widowed requires $£ 31,936 \mathrm{pm}, £ 21,453 \mathrm{pm}$ and $£ 32,259$, respectively. Values of around $£ 10,000 \mathrm{pm}$ are obtained for regularly talking to neighbours and meeting people, while close figures of $£ 9,000$ to $£ 10,000 \mathrm{pm}$ are also placed on social activities (going to the theatre/concert, out for drinks or attend local groups) at least once per week.

However, using an LR-test and formally testing for the parallel lines assumption, we reject the homogeneity of coefficients across SWB categories $\left(L R_{x_{133}^{2}}=2804.65\right)$, favoring the estimation of a less restricted model (i.e. generalized). Significance levels are changed both across variables and within happiness levels. More CV ratios now posses statistical significance, although SWB level 4, for any variable, hardly displays any. Looking at the significant CV

\footnotetext{
${ }^{6}$ The estimated marginal effects are given in the Appendix.

${ }^{7}$ Translating this into an equation $S W B(Y, X=0, Z)=S W B(Y+C V, X=1, Z)$ (Groot and van den Brink, 2006).

${ }^{8}$ Due to frequent use "Per month" is abbreviated to "pm".
} 
values of the generalized model (Table 4) a reduction in the size of the values is apparent, with differences between the average valuations of the standard (Table 3) and the generalized (Table 4) model ranging from $35 \%$ (cinema: several times) to $560 \%$ (stomach/digestion problems). Staying with the estimations of Table 4, variation is also observed across the different SWB categories, confirming that significant heterogeneity is ignored in the standard models. As before, the last 3 columns of Table 4 are informative of the variation across SWB levels for each variable. Contrary to the previous table, all percentage values are now above $10 \%$ while more than a third are over $80 \%$ (with a mean of $65 \%$ ). Continuing the previous example, someone could be compensated for a problem in their "Arms, legs, hands, etc." with $£ 1,249$ pm to $£ 4,933$ pm, again depending on their initial happiness category, with an average of about $£ 2,495 \mathrm{pm}$. Further, examination of the gradient of the significant $\mathrm{CV}$ values across SWB categories in the generalized model tends to indicate a decrease (increase) in the sizes of the positively (negatively) signed ratios as we move to a higher SWB category (i.e. more life satisfied individuals requiring smaller monetary compensations). Such result is consistently true (with the exception of "Arms, legs and hands etc.") when one compares the SWB levels 1 or 2 with level 5. However, clear patterns are difficult to be identified for the remaining levels. However, when reaching SWB level 6, significant $\mathrm{CV}$ ratios change signs, indicating negative required compensations, something that is not in line with our expectations and can only be qualitatively interpreted as no compensation required (explanations for such phenomenon in the next section).

Concentrating on the average $\mathrm{CV}$ ratios values, an individual requires about $£ 2,000$ to $£ 3,000 \mathrm{pm}$ to remain in his current SWB level for all health problems, with the exception of those suffering from anxiety/depression, who would need about $£ 8,000 \mathrm{pm}$. Being separated, divorced or widowed is valued at about $£ 6,298 \mathrm{pm}, £ 4,234 \mathrm{pm}$ and $£ 7,056$, respectively, while lack of most social relationships can be compensated with $£ 2,000$ to $£ 4,000$ pm.

\section{DISCUSSION}

Having estimated SWB equations, this study provides new monetary value estimates for a number of health conditions and social capital indicators, while past CV values of marital status and social relationships are also replicated. For situations where past attempts are available and standard estimation frameworks are used, our calculated values are largely comparable (Clark 
and Oswald, 2002; Powdthavee, 2008; Groot and van den Brink, 2006). However, once more flexible and appropriate modeling strategies are allowed, proximity between values is reduced. Relaxing the restrictive assumptions of the ordered probit results in substantial heterogeneity in the $\mathrm{CV}$ ratios across the six SWB levels, with average values considerably lower compared to the standard ordered/linear model implying that the values of the latter should be treated with caution. Such lower values could have significant implications in the various policy making contexts and settings if and when compensating variation methods are formally employed (Dolan and Peasgood, 2008; Oswald and Powdthavee, 2008).

Nevertheless, such a degree of heterogeneity comes at a cost, complicating the interpretation of the $\mathrm{CV}$ values and restricting their usefulness in policy/decisions making. Acquiring distinct values across SWB categories indicates distinct behavioral patterns across individuals and implies different rates of substitution. Thus, the practicality of a unique average value is lost, as any potential policy suggestion would now have to treat/weight individual differently. However, suggesting different treatment of individuals can lead to strategic behavior when answering the SWB questions (i.e. individuals not revealing their true satisfaction). Hence, although generalized models should be favoured from an econometric point of view, the simplicity of the more standard approaches is still attractive.

In any case, counterintuitive results from the generalized models require further explanation and/or treatment. Logical rationale as to why SWB level 4 displays hardly any significance compared to the other levels are difficult to find and this finding can probably be attributed to the data. Similarly, the change in sign of the CV valuations of SWB level 6 in Table 4 can be also difficult to interpret. Such change in the sign implies that individuals do not require any compensation for a worsening in their situation and in fact they are willing to pay for such change. However, rational explanations for negative required compensations are not probable and such valuations are unlikely to be realistic. It is more likely that these values are an artifact of the relationship between income and SWB. Under the generalized model marginal effects are allowed to change sign freely and although the marginal effects for the variables of interest change sign only once (i.e. positive and then negative or vice versa), income changes twice ${ }^{9}$ (see Appendix). Increases in absolute income decrease the probability of reporting the highest SWB

\footnotetext{
${ }^{9}$ From negative (SWB level 1 to 3) to positive (SWB level 4 to 5) and negative again (SWB level 6).
} 
level, quickly summarized as "money does not buy happiness" (Boes and Winkelmann, 2006a; Mentzakis and Moro, 2009). As Mentzakis and Moro (2009) show such a relationship is not present when relative income indicators are used. However, such treatment further creates questions about the different ways the notion of relative income can be expressed and the actual variable constructed.

\section{CONCLUSIONS}

This paper presents and compares monetary values for a variety of life and health situations. Formal testing and the presence of heterogeneity in the valuations rule in favor of less restrictive models, such as the generalized ordered response model, and against the commonly used standard linear or ordered response ones. Although explicitly incorporating unobserved heterogeneity in the estimations accounts for some sources of endogeneity, failing to account for the endogeneity of income is a potential limitation of the paper. However, such limitation should not bear much effect on the general findings regarding the properties of the $\mathrm{CV}$ ratios as endogeneity of income would be expected to similarly affect all specifications discussed. Replications of the findings with instrumented relative income indicators would be a step towards more realistic valuation estimates.

\section{ACKNOWLEDGEMENTS}

I am grateful to two anonymous reviewers for their valuable comments and suggestions. Thanks are also due to Paul Contoyannis for useful discussions and Evan Meredith and Jingjing Zhang for their comments on earlier drafts. Data from the British Household Panel Survey were supplied by the ESRC Data Archive. The usual disclaimer applies.

\section{REFERENCES}

Alesina A, Di Tella R, MacCulloch R. 2004. Inequality and happiness: Are Europeans and Americans different? Journal of Public Economics 88: 2009-2042.

Bateman I, Carson RT, Day B, Hanemann WM, Hanley N, Hett T, Jones A, Loomes G, Mourato S, Ozdemiroglu E, Pearce DW, Sugden R, Swanson J. 2002. Economic valuation with stated preferences techniques: A Manual. Edward Elgar: Cheltenham, UK. 
Blanchflower DG, Oswald AJ. 2004. Well-Being over time in Britain and the USA. Journal of Public Economics 88: 1359-1386.

Boes S. Winkelmann R. The effect of income on positive and negative subjective well-being. 2006a; Working Paper No. 0605.

Boes S, Winkelmann R. 2006b. Ordered response models. Allgemeines Statistisches Archiv 90: 165-180. Chamberlain G. 1982. Multivariate regression models for panel data. Journal of Econometrics 18: 5-46.

Clark AE, Frijters P, Shields MA. 2008. Relative income, happiness and utility: An explanation for the Easterlin paradox and other puzzles. Journal of Economic Literature 46: 95-144.

Clark AE, Etilé F, Postel-Vinay F, Senik C, van der Straeten K. 2005. Heterogeneity in reported wellbeing: Evidence from twelve European countries. The Economic Journal 115: C118-C132.

Clark AE, Oswald AJ. 2002. A simple statistical method for measuring how life events affect happiness. International Journal of Epidemiology 31: 1139-1144.

Di Tella R, MacCulloch RJ, Oswald AJ. 2001. Preferences over inflation and unemployment: Evidence from surveys of happiness. American Economic Review 91: 335-347.

Di Tella R, MacCulloch R. 2006. Some uses of happiness data in economics. Journal of Economic Perspectives 20: 25-25.

Dolan P, Peasgood T. 2008. Measuring well - being for public policy: preferences or experiences? The Journal of Legal Studies 37: S5-S31.

Easterlin RA. 2001. Income and happiness: Towards an unified theory. Economic Journal 111: 465-484.

Easterlin RA. 1995. Will raising the incomes of all increase the happiness of all? Journal of Economic Behavior and Organization 27: 35-47.

Easterlin Richard A. Does economic growth improve the human lot? Some empirical evidence. In: R. David. R. Reder, editors. Nations and households in economic growth: Essays in honor of Moses Abramovitz. New York: Academic Press, 1974.

Ferrer-i-Carbonell A, Frijters P. 2004. How important is methodology for the estimates of the determinants of happiness. The Economic Journal 114: 641-659.

Ferrer-i-Carbonell A, van Praag BMS. 2002. The subjective costs of health losses due to chronic diseases. An alternative model for monetary appraisal. Health Economics 11: 709-722.

Frey BS, Luechinger S, Stutzer A. Valuing public goods: The life satisfaction approach. 2004; No CESifo Working Paper No. 1158.

Frey BS, Stutzer A. 2002. What can economists learn from happiness research? Journal of Economic Literature 40: 402-435.

Frijters P, Shields MA, Haisken-DeNew JP. 2004. Money does matter! Evidence from increasing real incomes in East Germany following reunification. American Economic Review 94: 730-741.

Groot W, van den Brink, MH. 2006. The compensating income variation of cardiovascular disease. Health Economics 15: 1143-1148.

Groot W, van den Brink, MH. 2004. A direct method for estimating the compensating income variation for severe headache and migraine. Social Science and Medicine 58: 305-314.

Groot W. 2000. Adaptation and scale of reference bias in self-assessments of quality of life. Journal of Health Economics, 19: 403-420.

Headey B, Wooden M. 2004. The effects of wealth and income on subjective well-being and ill-being. The Economic Record 80: S24-S33.

Huppert FA, Whittington JE. 2003. Evidence for the independence of positive and negative well-being: Implications for quality of life assessment. British Journal of Health Psychology 8: 107-122. 
Kahneman D, Krueger AB. 2006. Developments in the measurement of subjective well-being. Journal of Economic Perspectives 20: 3-24.

Lelkes O. 2006. Tasting freedom: Happiness, religion and economic transition. Journal of Economic Behavior and Organization 59: 173-194.

Long JS, Freese J. 2005. Regression models for categorical outcomes using Stata, 2nd Edition. Stata Press: College Station, TX.

Maddala G. S. Limited-dependent and qualitative variables in econometrics. 1983. Econometric Society Monographs in Quantitative Economics, Cambridge, UK.

McClements L. 1977. Equivalence scales for children. Journal of Public Economics 8: 191-210.

Mentzakis E, Moro M. 2009. The poor, the rich and the happy: Exploring the link between income and subjective well-being. Journal of Socio-Economics 38: 147-158.

Mundlak Y. 1978. On the pooling of time series and cross-section data. Econometrica 1: 69-85.

Oswald A, Powdthavee N. 2008. Death, happiness, and the calculation of compensatory damages. The Journal of Legal Studies 37: S217-S251.

Powdthavee N. 2008. Putting a price tag on friends, relatives, and neighbours: Using surveys of life satisfaction to value social relationships. Journal of Socio-Economics 37: 1459-1480.

Smith VK. 2008. Reflections on the Literature. Review of Environmental Economics and Policy 2: 292308.

Terza J. 1985. Ordinal probit: A Generalisation. Communications in Statistics - Theory and Methods 14: $1-11$.

Van Praag BMS, Baarsma BE. 2005. Using happiness surveys to value intangibles: The case of airport noise. Economic Journal 115: 224-246.

Welsch H. 2006. Environment and happiness: Valuation of air pollution using life satisfaction data. Ecological Economics 58: 801-813.

Winkelmann L, Winkelmann R. 1998. Why are the unemployed so unhappy? Evidence from panel data. Economica 65: 1-15. 
Table 1. Overall life satisfaction distribution

\begin{tabular}{|c|c|c|}
\hline & Frequency & Percent \\
\hline $1=$ Not satisfied at all & 1,812 & 3.58 \\
\hline 2 & 3,054 & 6.03 \\
\hline 3 & 7,077 & 13.98 \\
\hline 4 & 14,928 & 29.49 \\
\hline 5 & 16,236 & 32.07 \\
\hline $6=$ Completely satisfied & 7,513 & 14.84 \\
\hline Total & 50,620 & 100.00 \\
\hline
\end{tabular}


Table 2. Definitions and descriptive statistics

\begin{tabular}{lllll}
\hline & Mean & Std. Dev. & Min & Max \\
\cline { 2 - 5 } Monthly household income & 2132.099 & 1667.615 & 0 & 66216.98 \\
Age & 46.50036 & 17.76776 & 18 & 99 \\
Age_sqr & 2477.97 & 1795.735 & 324 & 9801 \\
\# kids & .5943105 & .974565 & 0 & 9 \\
House size & 2.800672 & 1.357382 & 1 & 13 \\
\hline
\end{tabular}

Binary indicators (sample proportions)

Sex

Kids 0 to 4

Kids 5 to 11

Kids 12 to 18

Neighbourhood

Noise from neighbours

Street noise

Pollution/environmental problems

Vandalism or crime

Employment (ref: unemployed)

Part-time

Full-time

Education (ref: higher $/ 1^{\text {st }}$ degree)

HND, HNC, teaching/ A Levels

O Levels/ CSE

None

1. Marital Status (ref: married)

Separated

Divorced

Widowed

Never married

2. Health Problems

Arms, legs, hands, etc

Sight

Hearing

Skin conditions/allergy

Chest/breathing

Heart/blood pressure

Stomach or digestion

Diabetes

Anxiety, depression, et

Migraine

Other

3. How often talking to neighbors (ref: almost never)

Most days

Once/twice week

Once/twice month
.453

.117

.185

.155

.105

.160

.076

.178

.130

.466

.257

.293

.322

.022

.087

.079

.255

.295

.051

.087

.122

.138

.175

.084

.036

.086

.087

.050

.395

.380

.140 
4. How often meet people (ref: almost never)

Most days

Once/twice week

Once/twice month

5. How often go to the cinema (ref: almost never)

At least once week/month

Several times a year

6. How often go to theatre/concert (ref: almost never)

At least once week/month

Several times a year

7. How often: go out for a drink (ref: almost never)

At least once week

At least once month

Several times a year

8. How often: attend local groups (ref: almost never)

At least once week

At least once month 
Table 3. CV monetary valuations estimated from SWB equations using fixed effects linear and standard ordered probit Mundlak models (all figures in $£$ per month).

\begin{tabular}{|c|c|c|c|c|c|c|c|c|c|c|}
\hline \multirow[b]{3}{*}{ Health Problems } & \multirow[t]{2}{*}{ Linear } & \multicolumn{9}{|c|}{ Standard Ordered Probit } \\
\hline & & \multirow[b]{3}{*}{$9497.33 * *$} & \multirow[b]{3}{*}{$9348.89 * *$} & \multirow[b]{3}{*}{$9205.21 * *$} & \multirow[b]{3}{*}{$8794.08 * *$} & \multirow[b]{3}{*}{$9339.37 * *$} & \multirow{4}{*}{$\begin{array}{l}9014.75 * * \\
(4073.42)\end{array}$} & \multirow[t]{2}{*}{$\operatorname{Avg}^{a}$} & \multirow[t]{2}{*}{ S.D. ${ }^{a}$} & \multirow[t]{2}{*}{$\%$ of Avg. ${ }^{a}$} \\
\hline & \multirow[b]{2}{*}{$9265.74 * *$} & & & & & & & & & \\
\hline \multirow[t]{2}{*}{ Arms, legs, hands, etc } & & & & & & & & 9199.938 & 256.5594 & 2.788708 \\
\hline & (3912.14) & $(4333.2)$ & $(4249.47)$ & $(4172.71)$ & $(3966.61)$ & $(4242.38)$ & & & & \\
\hline \multirow[t]{2}{*}{ Sight } & 210.55 & -519.73 & -520.69 & -521.66 & -524.53 & -520.69 & -523.06 & & & \\
\hline & $(3176.76)$ & $(2698.16)$ & $(2708.06)$ & $(2718.09)$ & $(2748)$ & $(2708.1)$ & $(2732.65)$ & & & \\
\hline \multirow[t]{2}{*}{ Hearing } & $7025.77 *$ & $7031.57 *$ & $6876.11 *$ & $6724.09 *$ & $6285.23 *$ & $6868.29 *$ & $6518.15 *$ & 6717.24 & 273.1929 & 4.06704 \\
\hline & $(4079.59)$ & $(4258.69)$ & $(4114.71)$ & $(3977.74)$ & $(3595.39)$ & $(4104.73)$ & $(3797.46)$ & & & \\
\hline \multirow[t]{2}{*}{ Skin conditions/allergy } & 1126.78 & 856.6 & 854.42 & 852.23 & 845.78 & 854.39 & 849.11 & & & \\
\hline & $(2251.05)$ & $(2109.98)$ & (2099.3) & $(2088.68)$ & $(2057.61)$ & $(2099.07)$ & $(2073.63)$ & & & \\
\hline \multirow[t]{2}{*}{ Chest/breathing } & 1048.02 & 508.04 & 507.3 & 506.56 & 504.38 & 507.29 & 505.5 & & & \\
\hline & $(2677.67)$ & $(2320.13)$ & $(2313.41)$ & $(2306.7)$ & $(2286.87)$ & $(2313.31)$ & $(2297.08)$ & & & \\
\hline \multirow[t]{2}{*}{ Heart/blood pressure } & $7418.84 * *$ & $6801.26 *$ & $6684.61 *$ & $6570.28 *$ & $6239.57 *$ & $6679.08 *$ & $6414.68 *$ & 6564.914 & 205.752 & 3.134116 \\
\hline & $(3622.9)$ & $(3625.23)$ & $(3536.9)$ & $(3453.33)$ & $(3221.38)$ & $(3530.98)$ & $(3342.23)$ & & & \\
\hline \multirow[t]{2}{*}{ Stomach or digestion } & $8951.41 * *$ & $8634.1 *$ & $8399.83 * *$ & $8172.28 * *$ & $7518.93 * *$ & $8386.12 * *$ & $7868.05 * *$ & 8163.218 & 407.3603 & 4.990192 \\
\hline & $(4215.75)$ & $(4418.4)$ & $(4257.57)$ & (4106) & $(3687.03)$ & $(4245.42)$ & (3908.48) & & & \\
\hline \multirow[t]{2}{*}{ Diabetes } & -1807.52 & -2084.8 & -2100.95 & -2117.38 & -2166.44 & -2100.85 & -2141.5 & & & \\
\hline & (6130.82) & $(5254.29)$ & (5334.76) & $(5417.32)$ & (5665.38) & (5333.58) & (5539.78) & & & \\
\hline \multirow[t]{2}{*}{ Anxiety, depression } & $47631.34 * * *$ & $56351.99 * *$ & $48183.48 * *$ & $41422.91 * *$ & $24302.88 * *$ & $46700.79 * *$ & $34843.36 * *$ & 41967.57 & 11234.28 & 26.76895 \\
\hline & $(18231.66)$ & $(24073.39)$ & $(20487.87)$ & $(17554.14)$ & (10261.32) & (19826) & (14727.52 ) & & & \\
\hline \multirow[t]{2}{*}{ Migraine } & $6906.33 *$ & $6175.94 *$ & $6055.44 *$ & $5937.19 *$ & $5594.81 *$ & $6049.92 *$ & $5775.87 *$ & 5931.529 & 212.9549 & 3.590219 \\
\hline & $(3725.24)$ & $(3683.59)$ & $(3574.5)$ & $(3470.26)$ & $(3178.02)$ & $(3567.67)$ & (3331.2) & & & \\
\hline \multirow[t]{2}{*}{ Other } & $16671.8 * *$ & $17867.04 * *$ & $16842.04 * *$ & $15883.22 * *$ & $13213.38 * *$ & $16740.25 * *$ & $14693.52 * *$ & 15873.24 & 1681.203 & 10.59143 \\
\hline & $(6854.67)$ & $(8136.78)$ & (7599.73 ) & (7111.56) & (5798) & $(7540.55)$ & $(6520.48)$ & & & \\
\hline \multicolumn{11}{|l|}{ Marital Status } \\
\hline Separated & $33958.89 * *$ & $41202.98 * *$ & $36101.27 * *$ & $31709.08 * *$ & $20248.29 * *$ & $35276.38 * *$ & $27082.87 * *$ & 31936.81 & 7410.688 & 23.20422 \\
\hline
\end{tabular}




\begin{tabular}{|c|c|c|c|c|c|c|c|c|c|c|}
\hline & (13561.93) & $(18387.83)$ & $(15902.78)$ & $(13818.79)$ & $(8594.56)$ & $(15484.18)$ & (11688.35) & & & \\
\hline Divorced & $\begin{array}{l}22571.48 * * \\
(8902.95)\end{array}$ & $\begin{array}{l}24879.5 * * \\
(10975.14)\end{array}$ & $\begin{array}{l}23082.6 * * \\
(10109.82)\end{array}$ & $\begin{array}{l}21440.81 * * \\
(9336.51)\end{array}$ & $\begin{array}{l}16954.61 * * \\
(7282.84)\end{array}$ & $\begin{array}{l}22865.77 * * \\
(9998.76)\end{array}$ & $\begin{array}{l}19496.71 \text { ** } \\
(8437.3)\end{array}$ & 21453.33 & 2844.474 & 13.25889 \\
\hline Widowed & $\begin{array}{l}30919.83 * * \\
(12168.16)\end{array}$ & $\begin{array}{l}40535.49 * * \\
(17708.02)\end{array}$ & $\begin{array}{l}36004.24 * * \\
(15595.88)\end{array}$ & $\begin{array}{l}32075.39 * * \\
(13803.98)\end{array}$ & $\begin{array}{l}21769.47 * * \\
(9236.91)\end{array}$ & $\begin{array}{l}35288.68 * * \\
(15251.37)\end{array}$ & $\begin{array}{l}27880.92 * * \\
(11929.91)\end{array}$ & 32259.03 & 6647.37 & 20.60623 \\
\hline Never married & $\begin{array}{l}18841.78 * * \\
(7450.26)\end{array}$ & $\begin{array}{l}20033.38 * * \\
(8806.17)\end{array}$ & $\begin{array}{l}19260.35 * * \\
(8427.32)\end{array}$ & $\begin{array}{l}18540.03 * * \\
(8085.74)\end{array}$ & $\begin{array}{l}16542.73 * * \\
(7169.91)\end{array}$ & $\begin{array}{l}19178.51 * * \\
(8384.88)\end{array}$ & $\begin{array}{l}17656.21 * * \\
(7672.64)\end{array}$ & 18535.2 & 1259.112 & 6.793086 \\
\hline \multicolumn{11}{|c|}{ Frequency of talking to neighbors } \\
\hline Most days & $\begin{array}{l}-11238.41^{* *} \\
(5061.73)\end{array}$ & $\begin{array}{l}-10528.42 * * \\
(5004.71)\end{array}$ & $\begin{array}{l}-10609.98 * * \\
(5043.91)\end{array}$ & $\begin{array}{l}-10698.63 * * \\
(5092.06)\end{array}$ & $\begin{array}{l}-10977.6 * * \\
(5260.07)\end{array}$ & $\begin{array}{l}-10600.76 \text { ** } \\
(5035.49)\end{array}$ & $\begin{array}{l}-10845.34 * * \\
(5176.73)\end{array}$ & -10710.1 & 170.273 & 1.589833 \\
\hline Once/twice week & $\begin{array}{l}-7461.89 * \\
(3817.85)\end{array}$ & $\begin{array}{l}-6855.51 * \\
(3618.85)\end{array}$ & $\begin{array}{l}-6897.43 * \\
(3644.64)\end{array}$ & $\begin{array}{l}-6941.52 * \\
(3674.72)\end{array}$ & $\begin{array}{l}-7076.73 * \\
(3776.3)\end{array}$ & $\begin{array}{l}-6895 * \\
(3641.12)\end{array}$ & $\begin{array}{l}-7010.37 * \\
(3724.27)\end{array}$ & -6946.09 & 82.9484 & 1.194174 \\
\hline Once/twice month & $\begin{array}{l}-2838.74 \\
(2793.86)\end{array}$ & $\begin{array}{l}-2393.21 \\
(2465.75)\end{array}$ & $\begin{array}{l}-2409.61 \\
(2496.17)\end{array}$ & $\begin{array}{l}-2426.3 \\
(2527.6)\end{array}$ & $\begin{array}{l}-2476.15 \\
(2623.68)\end{array}$ & $\begin{array}{l}-2409.49 \\
(2495.35)\end{array}$ & $\begin{array}{l}-2450.82 \\
(2574.73)\end{array}$ & & & \\
\hline \multicolumn{11}{|l|}{ Frequency of meeting people } \\
\hline Most days & $\begin{array}{l}-11058.36^{* * *} \\
(5526.87)\end{array}$ & $\begin{array}{l}-9951.12 * \\
(5363.75)\end{array}$ & $\begin{array}{l}-9989.22 * \\
(5385.29)\end{array}$ & $\begin{array}{l}-10032.6 * \\
(5414.55)\end{array}$ & $\begin{array}{l}-10173.66 * \\
(5524.86)\end{array}$ & $\begin{array}{l}-9982.03 * \\
(5376.34)\end{array}$ & $\begin{array}{l}-10109.61 * \\
(5472.56)\end{array}$ & -10039.7 & 85.56161 & 0.852232 \\
\hline Once/twice week & $\begin{array}{l}-9433.48 * \\
(5056.31)\end{array}$ & $\begin{array}{l}-8441.79 * \\
(4831.23)\end{array}$ & $\begin{array}{l}-8481.72 * \\
(4859.08)\end{array}$ & $\begin{array}{l}-8525.1 * \\
(4892.87)\end{array}$ & $\begin{array}{l}-8661.54 * \\
(5010.89)\end{array}$ & $\begin{array}{l}-8477.3 * \\
(4852.55)\end{array}$ & $\begin{array}{l}-8596.77 * \\
(4953.14)\end{array}$ & -8530.7 & 83.27407 & 0.976169 \\
\hline Once/twice month & $\begin{array}{l}-5193.99 \\
(4185.82)\end{array}$ & $\begin{array}{l}-4487.97 \\
(3735.99)\end{array}$ & $\begin{array}{l}-4550.71 \\
(3826.68)\end{array}$ & $\begin{array}{l}-4615.23 \\
(3921.43)\end{array}$ & $\begin{array}{l}-4809.51 \\
(4213.19)\end{array}$ & $\begin{array}{l}-4549.3 \\
(3822.66)\end{array}$ & $\begin{array}{l}-4711.85 \\
(4066.74)\end{array}$ & & & \\
\hline \multicolumn{11}{|l|}{ How often go to the cinema } \\
\hline At least once week/month & $\begin{array}{l}-5235.36 \\
(3228.82)\end{array}$ & $\begin{array}{l}-4614.53 \\
(2991.71)\end{array}$ & $\begin{array}{l}-4675.11 \\
(3051.96)\end{array}$ & $\begin{array}{l}-4737.41 \\
(3116.14)\end{array}$ & $\begin{array}{l}-4925.04 \\
(3315.44)\end{array}$ & $\begin{array}{l}-4673.74 \\
(3049.5)\end{array}$ & $\begin{array}{l}-4830.74 \\
(3214.23)\end{array}$ & & & \\
\hline Several times a year & $\begin{array}{l}-4726.01 * \\
(2442.59)\end{array}$ & $\begin{array}{l}-4317.27 * \\
(2421.47)\end{array}$ & $\begin{array}{l}-4345.56 * \\
(2441.81)\end{array}$ & $\begin{array}{l}-4374.64 * \\
(2464.58)\end{array}$ & $\begin{array}{l}-4462.2 * \\
(2537.91)\end{array}$ & $\begin{array}{l}-4344.95 * \\
(2440.67)\end{array}$ & $\begin{array}{l}-4418.17 * \\
(2499.57)\end{array}$ & -4377.13 & 53.92817 & 1.232043 \\
\hline \multicolumn{11}{|c|}{ How often go to theatre/concert } \\
\hline At least once week/month & $\begin{array}{l}-11239.02^{* *} \\
(5307.92)\end{array}$ & $\begin{array}{l}-9775.12 * * \\
(4888.07)\end{array}$ & $\begin{array}{l}-10135.99 * * \\
(5118.78)\end{array}$ & $\begin{array}{l}-10517.57 * \\
(5371.89)\end{array}$ & $\begin{array}{l}-11694.73 * \\
(6180.14)\end{array}$ & $\begin{array}{l}-10109.8 * * \\
(5095.22)\end{array}$ & $\begin{array}{l}-11122.26 * \\
(5786.53)\end{array}$ & -10559.3 & 721.6708 & 6.834492 \\
\hline Several times a year & $-7698.82 * *$ & $-7125.83 * *$ & $-7205.12 * *$ & $-7287.69 * *$ & $-7539.01 * *$ & $-7201.7 * *$ & $-7414.46 * *$ & -7295.64 & 154.4439 & 2.116935 \\
\hline
\end{tabular}




\begin{tabular}{|c|c|c|c|c|c|c|c|c|c|c|}
\hline \multirow{2}{*}{\multicolumn{11}{|c|}{ How often go out for a drink }} \\
\hline & & & & & & & & & & \\
\hline \multirow[t]{2}{*}{ At least once week } & $-10084.8 * *$ & $-9049.93 * *$ & $-9175.5 * *$ & $-9307.53 * *$ & $-9712.57 * *$ & $-9168.04 * *$ & $-9513.97 * *$ & -9321.26 & 248.5114 & 2.666072 \\
\hline & $(4602.67)$ & $(4454.66)$ & $(4527.6)$ & $(4608.19)$ & (4870.64) & $(4520.02)$ & (4739.02) & & & \\
\hline \multirow[t]{2}{*}{ At least once month } & $-5346.43 *$ & $-4921.36 *$ & $-4976.02 *$ & $-5032.28 *$ & -5201.83 & $-4974.71 *$ & -5116.69 & -4976.09 & 45.29382 & 0.910229 \\
\hline & (3040.65) & $(2928.65)$ & $(2975.45)$ & (3025.04) & $(3181.76)$ & $(2972.84)$ & (3101.84) & & & \\
\hline \multirow[t]{2}{*}{ Several times a year } & -984.05 & -465.95 & -466.49 & -467.04 & -468.67 & -466.5 & -467.83 & & & \\
\hline & (2033.65) & (1939.55) & (1944.09) & $(1948.59)$ & (1962.09) & (1944.06) & (1955.16) & & & \\
\hline \multicolumn{11}{|c|}{ How often attend local groups } \\
\hline \multirow[t]{2}{*}{ At least once week } & $-10312.7 * *$ & $-9467.59 * *$ & $-9796.19 * *$ & $-10142.89 * *$ & $-11210.46 *$ & $-9773.7 * *$ & $-10689.91 * *$ & -10180.1 & 654.6999 & 6.43116 \\
\hline & $(4784.28)$ & $(4645.58)$ & $(4845.95)$ & $(5065.35)$ & $(5765.36)$ & $(4826.56)$ & $(5422.58)$ & & & \\
\hline \multirow[t]{2}{*}{ At least once month } & -3970.99 & -3374.43 & -3412.66 & -3451.78 & -3569.13 & -3412.09 & -3509.83 & & & \\
\hline & (2767.33) & $(2652.34)$ & (2703) & $(2756.25)$ & (2919.17) & $(2701.45)$ & (2836.39) & & & \\
\hline \multirow[t]{2}{*}{ Several times a year } & -1645.83 & -1670.83 & -1680.63 & -1690.59 & -1720.26 & -1680.61 & -1705.14 & & & \\
\hline & (2351.9) & $(2406.45)$ & $(2433.21)$ & $(2460.85)$ & $(2544.03)$ & $(2432.97)$ & (2501.52) & & & \\
\hline
\end{tabular}

Average and standard deviation are computed as the mean and standard deviations of all the significant ratios, while the size of SD relative to the Avg.

Ratios' standard errors in parentheses (computed with the delta method).

* significant at $10 \%$; ** significant at $5 \%$; *** significant at $1 \%$ 
Table 4. CV monetary valuations estimated from SWB equations using generalized ordered probit Mundlak models (all figures in £ per month).

\begin{tabular}{|c|c|c|c|c|c|c|c|c|c|}
\hline \multirow[b]{3}{*}{ Health Problems } & \multicolumn{9}{|c|}{ Generalized ordered probit } \\
\hline & \multirow[b]{3}{*}{$4933.73 * * *$} & \multirow[b]{3}{*}{$1249.49 *$} & \multirow{4}{*}{$\begin{array}{l}2260.85 * * * \\
(512.52)\end{array}$} & \multirow{4}{*}{$\begin{array}{l}-504.29 \\
(997.88)\end{array}$} & \multirow{4}{*}{$\begin{array}{l}1537.54 \text { *** } \\
(267.98)\end{array}$} & \multirow{4}{*}{$\begin{array}{l}-243.94 \\
(311.99)\end{array}$} & \multirow{4}{*}{$\begin{array}{l}\text { Avg. }^{\text {a }} \\
2495.403\end{array}$} & \multirow{4}{*}{$\begin{array}{r}\text { S.D. }{ }^{a} \\
1680.306\end{array}$} & \multirow{4}{*}{$\begin{array}{r}\% \text { of Avg. }{ }^{a} \\
67.33605\end{array}$} \\
\hline & & & & & & & & & \\
\hline Arms, legs, hands, etc & & & & & & & & & \\
\hline & $(1340.92)$ & $(671.12)$ & & & & & & & \\
\hline \multirow[t]{2}{*}{ Sight } & -832.16 & 1317.29 & 571.64 & 2572.13 & 103.23 & 561.86 & & & \\
\hline & (1258.66) & $(1136.85)$ & $(766.91)$ & $(1963.38)$ & $(431.87)$ & $(572.67)$ & & & \\
\hline \multirow[t]{2}{*}{ Hearing } & $4382.28 * *$ & 1616.82 & 772.67 & -128.06 & $655.36 *$ & -561.35 & 2518.823 & 2635.328 & 104.6254 \\
\hline & $(1725.3)$ & $(1082.22)$ & $(693.35)$ & $(1509.58)$ & $(375.65)$ & $(495.4)$ & & & \\
\hline \multirow[t]{2}{*}{ Skin conditions/allergy } & $-1650.67 *$ & 223.23 & -316.25 & -2474.72 & -161.78 & $-918.79 * *$ & -1284.73 & 517.516 & 40.28218 \\
\hline & $(987.66)$ & $(796.74)$ & $(534.64)$ & $(1505.99)$ & $(325.39)$ & $(424.9)$ & & & \\
\hline \multirow[t]{2}{*}{ Chest/breathing } & $1878.4 *$ & 1350.44 & $1099.83 *$ & $5230 * *$ & $560.86 *$ & $1696.72 * * *$ & 2093.162 & 1828.776 & 87.36905 \\
\hline & $(1088.93)$ & $(831.59)$ & $(564.75)$ & (2032.81) & $(314.04)$ & $(497.29)$ & & & \\
\hline \multirow[t]{2}{*}{ Heart/blood pressure } & $3156.34 * *$ & $4721.06 * * *$ & 107.5 & 21.34 & $1360.87 * * *$ & 498.33 & 3079.426 & 1681.414 & 54.60155 \\
\hline & $(1239.28)$ & $(1156.22)$ & $(523.25)$ & (1185.14) & $(306.55)$ & $(397.36)$ & & & \\
\hline \multirow[t]{2}{*}{ Stomach or digestion } & 1488.66 & $3352.34 * * *$ & 644.32 & -2125.55 & $955.25 * *$ & $-878.13 *$ & 1229.529 & 1740.776 & 141.5807 \\
\hline & (1137.83) & $(1093.75)$ & (619.14) & (1635.06) & $(370.87)$ & $(467.03)$ & & & \\
\hline \multirow[t]{2}{*}{ Diabetes } & 730.01 & 721 & 103.69 & 325.88 & 734.65 & 1037.82 & & & \\
\hline & $(2030.53)$ & $(1646.1)$ & (1106.55) & $(2340.55)$ & $(604.45)$ & $(971.35)$ & & & \\
\hline \multirow[t]{2}{*}{ Anxiety, depression } & $17131.25 * * *$ & $13604.24 * * *$ & $5890.67 * * *$ & 2616.53 & $4480.59 * * *$ & $-1786.52 * * *$ & 7864.046 & 7538.34 & 95.85828 \\
\hline & (3869.75) & (2511.09) & (999.62) & (1735.53) & $(502.88)$ & $(527.17)$ & & & \\
\hline \multirow[t]{2}{*}{ Migraine } & -16.1 & $2623.81 * *$ & $1458.52 * *$ & -1260.02 & $1193.55 * * *$ & -279.5 & 1758.627 & 760.8948 & 43.26641 \\
\hline & $(1072.57)$ & $(1048.43)$ & $(660.01)$ & $(1536.61)$ & $(386.31)$ & $(509.05)$ & & & \\
\hline \multirow[t]{2}{*}{ Other } & $4162.71 * *$ & $4339.78 * * *$ & $2972.31 * * *$ & -2145.78 & $2159.15 * * *$ & $-1164.12 * *$ & 2493.967 & 2231.267 & 89.46659 \\
\hline & $(1737.31)$ & (1404.38) & $(872.72)$ & (1959.6) & $(458.64)$ & $(539.18)$ & & & \\
\hline \multicolumn{10}{|l|}{ Marital Status } \\
\hline \multirow[t]{2}{*}{ Separated } & $13663.89 * * *$ & $9858.29 * * *$ & $6095.24 * * *$ & 1113.97 & $3892.77 * * *$ & $-2019.15 * *$ & 6298.207 & 5956.788 & 94.57911 \\
\hline & $(4245.15)$ & $(2756.77)$ & $(1524.3)$ & $(2906.36)$ & $(728.13)$ & $(850.26)$ & & & \\
\hline Divorced & $9835.86 * * *$ & $5588.18 * * *$ & $4462.4 * * *$ & 1746.2 & $2497.15 * * *$ & $-1208.86 * *$ & 4234.946 & 4059.194 & 95.84996 \\
\hline
\end{tabular}




\begin{tabular}{|c|c|c|c|c|c|c|c|c|c|}
\hline & $(2626.47)$ & $(1458.92)$ & $(904.26)$ & $(1638.1)$ & $(423.62)$ & $(494.86)$ & & & \\
\hline \multirow[t]{2}{*}{ Widowed } & $17822.5 * * *$ & $7639.16 * * *$ & $7425.93 * * *$ & 2607.56 & $4189.37 * * *$ & $-1793.6 * * *$ & 7056.671 & 7122.629 & 100.9347 \\
\hline & $(4477.4)$ & $(1947.45)$ & $(1283.17)$ & $(1809.12)$ & $(496.25)$ & $(497.32)$ & & & \\
\hline \multirow[t]{2}{*}{ Never married } & $6554.67 * * *$ & $5301.71 * * *$ & $4317.96 * * *$ & -118.59 & $2338.37 * * *$ & $-1618.27 * * *$ & 3378.888 & 3190.571 & 94.42665 \\
\hline & $(1798.29)$ & $(1227.62)$ & $(765.12)$ & $(1143.9)$ & $(345.9)$ & $(418.83)$ & & & \\
\hline \multicolumn{10}{|c|}{ Frequency of talking to neighbors } \\
\hline \multirow[t]{2}{*}{ Most days } & $-4033.77 * * *$ & $-2861.74 * * *$ & -1035.22 & 1618.17 & $-1413.65 * * *$ & 362.31 & -2769.72 & 1312.484 & 47.38682 \\
\hline & $(1358.43)$ & $(1007.78)$ & $(644.45)$ & $(1664.86)$ & $(404.77)$ & $(518.99)$ & & & \\
\hline \multirow[t]{2}{*}{ Once/twice week } & $-5642.37 * * *$ & $-2878.86 * * *$ & -903.22 & -1639.79 & $-1688.84 * * *$ & $-1352.31 * * *$ & -2890.6 & 1947.9 & 67.38747 \\
\hline & $(1547.81)$ & $(982.87)$ & $(622.7)$ & $(1648.44)$ & (406.1) & $(509.94)$ & & & \\
\hline \multirow[t]{2}{*}{ Once/twice month } & $-4902 * * *$ & $-1710.97 *$ & 431.76 & -1409.96 & $-1277.27 * * *$ & $-1971.18 * * *$ & -2465.36 & 1649.453 & 66.90524 \\
\hline & $(1392.39)$ & (956.09) & $(681.6)$ & $(1813.35)$ & $(440.06)$ & $(540.15)$ & & & \\
\hline \multicolumn{10}{|l|}{ Frequency of meeting people } \\
\hline \multirow[t]{2}{*}{ Most days } & -2590.13 & $-3893.14 * * *$ & -525.24 & 623.79 & -962.33 & 461.41 & -3893.15 & & \\
\hline & $(1679.8)$ & $(1478.54)$ & (949.53) & $(2438.16)$ & $(600.83)$ & $(766.93)$ & & & \\
\hline \multirow[t]{2}{*}{ Once/twice week } & $-4072.97 * *$ & $-3763.71 * * *$ & -589.08 & -1322.6 & $-1045.9 *$ & -282.71 & -2960.86 & 1665.596 & 56.25373 \\
\hline & $(1756.7)$ & $(1444.19)$ & $(937.55)$ & $(2452.07)$ & $(597.87)$ & $(755.81)$ & & & \\
\hline \multirow[t]{2}{*}{ Once/twice month } & $-3405.57 * *$ & $-2540.12 *$ & 77.61 & -1943.52 & -658.69 & -809.03 & -2972.84 & 611.9642 & 20.58515 \\
\hline & $(1603.54)$ & $(1350.6)$ & $(987.59)$ & $(2663.87)$ & $(634.55)$ & $(772.36)$ & & & \\
\hline \multicolumn{10}{|l|}{ How often go to the cinema } \\
\hline \multirow[t]{2}{*}{ At least once week/month } & -1496.88 & $-2883.02 * * *$ & $-2381.51 * * *$ & $-2929.92 *$ & $-1818.73 * * *$ & $-1597.74 * * *$ & -2322.18 & 605.3254 & 26.06707 \\
\hline & $(1163.56)$ & $(958.53)$ & $(644.34)$ & $(1685.94)$ & $(388.59)$ & $(476.8)$ & & & \\
\hline \multirow[t]{2}{*}{ Several times a year } & $-4861.69 * * *$ & $-2830.24 * * *$ & $-2274.59 * * *$ & $-5350.01 * * *$ & $-1915.14 * * *$ & $-2404.35 * * *$ & -3272.67 & 1458.02 & 44.55138 \\
\hline & $(1275.82)$ & $(791.41)$ & $(515.09)$ & $(1966.62)$ & $(300.87)$ & $(398.8)$ & & & \\
\hline \multicolumn{10}{|c|}{ How often go to theatre/concert } \\
\hline \multirow[t]{2}{*}{ At least once week/month } & -2250.35 & $-3558.32 * * *$ & $-1803.13 * *$ & 2837.86 & $-2253.8 * * *$ & -78.71 & -2538.42 & 911.5496 & 35.91014 \\
\hline & $(1593.25)$ & $(1281.17)$ & $(847.66)$ & $(2179.76)$ & $(530.08)$ & $(633.18)$ & & & \\
\hline \multirow[t]{2}{*}{ Several times a year } & $-5383.19 * * *$ & $-2637.14 * * *$ & $-1735.63 * * *$ & $-2055.43 *$ & $-1453.05 * * *$ & $-599.15 *$ & -2310.6 & 1649.702 & 71.3973 \\
\hline & (1353.93) & (762.71) & $(465.07)$ & $(1173.45)$ & $(268.23)$ & (314.44) & & & \\
\hline
\end{tabular}




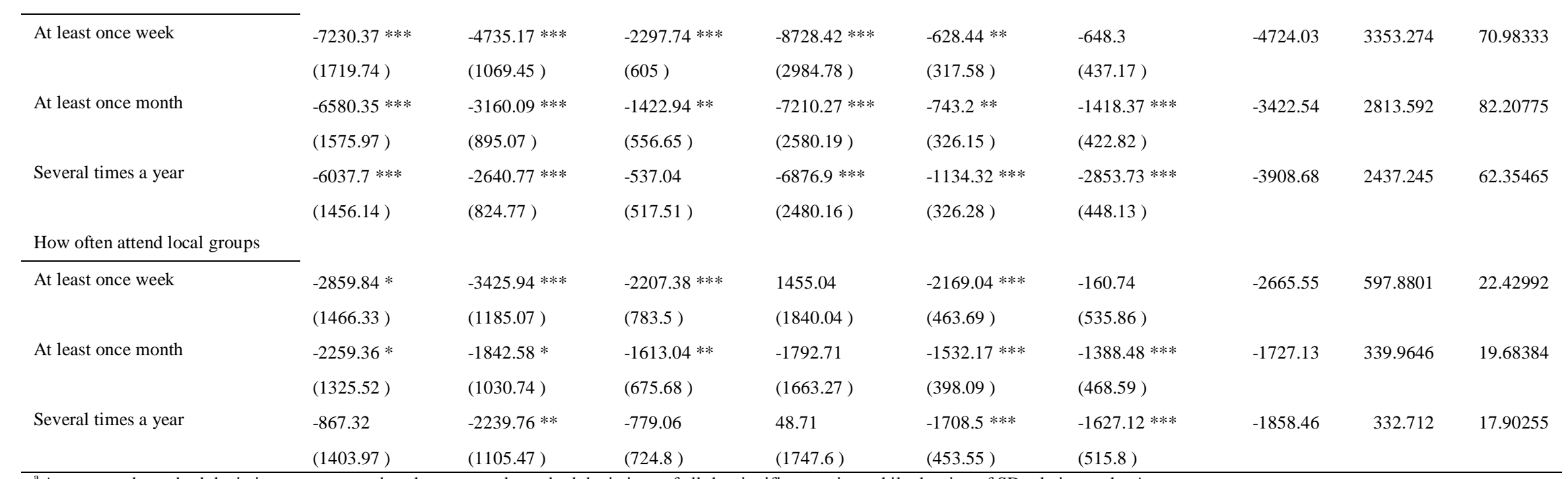

${ }^{a}$ Average and standard deviation are computed as the mean and standard deviations of all the significant ratios, while the size of SD relative to the Avg.

Ratios' standard errors in parentheses (computed with the delta method).

* significant at $10 \%$; * significant at $5 \%$; *** significant at $1 \%$ 


\section{Appendix A}

Table A1: Marginal effects for the fixed effects linear and random effects ordered probit Mundlak estimations

\begin{tabular}{|c|c|c|c|c|c|c|c|}
\hline \multirow[b]{3}{*}{ Equiv. Monthly House. Income } & \multirow[t]{2}{*}{ Linear } & \multicolumn{6}{|c|}{ Oprobit } \\
\hline & & 1 & 2 & 3 & 4 & 5 & 6 \\
\hline & $\begin{array}{c}9.42 \mathrm{e}-06^{* * * *} \\
(3.56 \mathrm{e}-06)\end{array}$ & $\begin{array}{c}-4.87 \mathrm{e}-07 * * \\
(2.05 \mathrm{e}-07)\end{array}$ & $\begin{array}{c}-7.62 \mathrm{e}-07 * * \\
(3.20 \mathrm{e}-07)\end{array}$ & $\begin{array}{c}-1.31 \mathrm{e}-06 * * \\
(5.50 \mathrm{e}-07)\end{array}$ & $\begin{array}{c}-9.12 \mathrm{e}-07 * * \\
(3.83 \mathrm{e}-07)\end{array}$ & $\begin{array}{c}1.66 \mathrm{e}-06^{* *} \\
(6.96 \mathrm{e}-07)\end{array}$ & $\begin{array}{l}1.81 \mathrm{e}-06^{* *} \\
(7.62 \mathrm{e}-07)\end{array}$ \\
\hline Arms, legs, hands, etc & $\begin{array}{c}-0.0872 * * * \\
(0.0156)\end{array}$ & $\begin{array}{c}0.00462 * * * \\
(0.000815)\end{array}$ & $\begin{array}{c}0.00713 * * * \\
(0.00123)\end{array}$ & $\begin{array}{c}0.0120 * * * \\
(0.00205)\end{array}$ & $\begin{array}{c}0.00802 * * * \\
(0.00131)\end{array}$ & $\begin{array}{c}-0.0155^{* * * *} \\
(0.00266)\end{array}$ & $\begin{array}{c}-0.0163 * * * \\
(0.00272)\end{array}$ \\
\hline Sight & $\begin{array}{c}-0.00198 \\
(0.0299)\end{array}$ & $\begin{array}{c}-0.000253 \\
(0.00131)\end{array}$ & $\begin{array}{c}-0.000397 \\
(0.00206)\end{array}$ & $\begin{array}{l}-0.000683 \\
(0.00355)\end{array}$ & $\begin{array}{c}-0.000478 \\
(0.00250)\end{array}$ & $\begin{array}{c}0.000863 \\
(0.00447)\end{array}$ & $\begin{array}{l}0.000948 \\
(0.00494)\end{array}$ \\
\hline Hearing & $\begin{array}{c}-0.0661 * * \\
(0.0291)\end{array}$ & $\begin{array}{c}0.00342 * * \\
(0.00149)\end{array}$ & $\begin{array}{c}0.00524 * * \\
(0.00223)\end{array}$ & $\begin{array}{c}0.00880 * * \\
(0.00366)\end{array}$ & $\begin{array}{c}0.00573 * * * \\
(0.00222)\end{array}$ & $\begin{array}{l}-0.0114 * * \\
(0.00483)\end{array}$ & $\begin{array}{l}-0.0118 * * \\
(0.00477)\end{array}$ \\
\hline Skin conditions/allergy & $\begin{array}{l}-0.0106 \\
(0.0209)\end{array}$ & $\begin{array}{l}0.000417 \\
(0.00101)\end{array}$ & $\begin{array}{l}0.000651 \\
(0.00158)\end{array}$ & $\begin{array}{c}0.00112 \\
(0.00269)\end{array}$ & $\begin{array}{l}0.000771 \\
(0.00185)\end{array}$ & $\begin{array}{l}-0.00142 \\
(0.00343)\end{array}$ & $\begin{array}{l}-0.00154 \\
(0.00370)\end{array}$ \\
\hline Chest/breathing & $\begin{array}{l}-0.00987 \\
(0.0249)\end{array}$ & $\begin{array}{l}0.000247 \\
(0.00112)\end{array}$ & $\begin{array}{l}0.000387 \\
(0.00176)\end{array}$ & $\begin{array}{l}0.000663 \\
(0.00301)\end{array}$ & $\begin{array}{c}0.000460 \\
(0.00208)\end{array}$ & $\begin{array}{l}-0.000840 \\
(0.00382)\end{array}$ & $\begin{array}{r}-0.000916 \\
(0.00415)\end{array}$ \\
\hline Heart/blood pressure & $\begin{array}{c}-0.0699 * * * \\
(0.0220)\end{array}$ & $\begin{array}{c}0.00331 * * * \\
(0.00108)\end{array}$ & $\begin{array}{c}0.00510 * * * \\
(0.00164)\end{array}$ & $\begin{array}{c}0.00860 * * * \\
(0.00271)\end{array}$ & $\begin{array}{c}0.00569 * * * \\
(0.00170)\end{array}$ & $\begin{array}{c}-0.0111 * * * \\
(0.00355)\end{array}$ & $\begin{array}{c}-0.0116^{* * * *} \\
(0.00358)\end{array}$ \\
\hline Stomach or digestion & $\begin{array}{c}-0.0843 * * * \\
(0.0241)\end{array}$ & $\begin{array}{c}0.00420 * * * \\
(0.00122)\end{array}$ & $\begin{array}{c}0.00640 * * * \\
(0.00181)\end{array}$ & $\begin{array}{c}0.0107 * * * \\
(0.00294)\end{array}$ & $\begin{array}{c}0.00685^{* * *} * \\
(0.00173)\end{array}$ & $\begin{array}{c}-0.0139 * * * \\
(0.00392)\end{array}$ & $\begin{array}{c}-0.0143 * * * \\
(0.00378)\end{array}$ \\
\hline Diabetes & $\begin{array}{c}0.0170 \\
(0.0574)\end{array}$ & $\begin{array}{l}-0.00101 \\
(0.00252)\end{array}$ & $\begin{array}{l}-0.00160 \\
(0.00401)\end{array}$ & $\begin{array}{c}-0.00277 \\
(0.00699)\end{array}$ & $\begin{array}{c}-0.00197 \\
(0.00510)\end{array}$ & $\begin{array}{c}0.00348 \\
(0.00871)\end{array}$ & $\begin{array}{c}0.00388 \\
(0.00991)\end{array}$ \\
\hline Anxiety, depression & $\begin{array}{c}-0.448 * * * \\
(0.0281)\end{array}$ & $\begin{array}{c}0.0274 * * * \\
(0.00202)\end{array}$ & $\begin{array}{c}0.0367 * * * \\
(0.00235)\end{array}$ & $\begin{array}{c}0.0542 * * * \\
(0.00294)\end{array}$ & $\begin{array}{l}0.0222 * * * \\
(0.000813)\end{array}$ & $\begin{array}{c}-0.0774 * * * \\
(0.00461)\end{array}$ & $\begin{array}{c}-0.0632 * * * * \\
(0.00289)\end{array}$ \\
\hline Migraine & $\begin{array}{c}-0.0650 * * \\
(0.0254)\end{array}$ & $\begin{array}{c}0.00301 * * \\
(0.00127)\end{array}$ & $\begin{array}{c}0.00462 * * \\
(0.00191)\end{array}$ & $\begin{array}{c}0.00777 * * \\
(0.00316)\end{array}$ & $\begin{array}{c}0.00510 * * * \\
(0.00195)\end{array}$ & $\begin{array}{l}-0.0100 * * \\
(0.00415)\end{array}$ & $\begin{array}{c}-0.0105^{* *} * \\
(0.00414)\end{array}$ \\
\hline Marital Status & $\begin{array}{c}-0.157 * * * * \\
(0.0262)\end{array}$ & $\begin{array}{c}0.00870 * * * \\
(0.00151)\end{array}$ & $\begin{array}{c}0.0128 * * * \\
(0.00211)\end{array}$ & $\begin{array}{c}0.0208 * * * \\
(0.00321)\end{array}$ & $\begin{array}{c}0.0120^{* * * *} \\
(0.00151)\end{array}$ & $\begin{array}{c}-0.0277 * * * \\
(0.00449)\end{array}$ & $\begin{array}{c}-0.0266^{* * * *} \\
(0.00380)\end{array}$ \\
\hline Separated & $\begin{array}{c}-0.320 * * * \\
(0.0413)\end{array}$ & $\begin{array}{c}0.0201 * * * \\
(0.00298)\end{array}$ & $\begin{array}{c}0.0275 * * * \\
(0.00362)\end{array}$ & $\begin{array}{c}0.0415 * * * \\
(0.00478)\end{array}$ & $\begin{array}{c}0.0185 * * * \\
(0.00105)\end{array}$ & $\begin{array}{c}-0.0584 * * * \\
(0.00739)\end{array}$ & $\begin{array}{c}-0.0491 * * * \\
(0.00484)\end{array}$ \\
\hline Divorced & $\begin{array}{c}-0.213 * * * * \\
(0.0254)\end{array}$ & $\begin{array}{l}0.0121 * * * \\
(0.00160)\end{array}$ & $\begin{array}{c}0.0176 * * * \\
(0.00216)\end{array}$ & $\begin{array}{c}0.0281 * * * \\
(0.00320)\end{array}$ & $\begin{array}{l}0.0155^{* * * *} \\
(0.00135)\end{array}$ & $\begin{array}{c}-0.0379 * * * \\
(0.00457)\end{array}$ & $\begin{array}{c}-0.0353 * * * * \\
(0.00366)\end{array}$ \\
\hline Widowed & $\begin{array}{c}-0.291 * * * \\
(0.0331)\end{array}$ & $\begin{array}{c}0.0197 * * * \\
(0.00232)\end{array}$ & $\begin{array}{c}0.0274 * * * \\
(0.00287)\end{array}$ & $\begin{array}{c}0.0420 * * * \\
(0.00389)\end{array}$ & $\begin{array}{c}0.0198 * * * \\
(0.00111)\end{array}$ & $\begin{array}{c}-0.0585^{* * * *} * \\
(0.00588)\end{array}$ & $\begin{array}{c}-0.0505^{* * *} * \\
(0.00408)\end{array}$ \\
\hline Never married & $\begin{array}{c}-0.177 * * * * \\
(0.0203)\end{array}$ & $\begin{array}{c}0.00975 * * * \\
(0.00124)\end{array}$ & $\begin{array}{c}0.0147 * * * \\
(0.00178)\end{array}$ & $\begin{array}{c}0.0243 * * * \\
(0.00283)\end{array}$ & $\begin{array}{c}0.0151 * * * \\
(0.00158)\end{array}$ & $\begin{array}{c}-0.0318 * * * \\
(0.00382)\end{array}$ & $\begin{array}{c}-0.0320 * * * \\
(0.00355)\end{array}$ \\
\hline Frequency of talking to neighbors & & & & & & & \\
\hline Most days & $\begin{array}{c}0.106^{* * *} \\
(0.0258)\end{array}$ & $\begin{array}{c}-0.00512 * * * \\
(0.00113)\end{array}$ & $\begin{array}{c}-0.00809^{* * * *} \\
(0.00180)\end{array}$ & $\begin{array}{c}-0.0140 * * * \\
(0.00313)\end{array}$ & $\begin{array}{c}-0.0100 * * * \\
(0.00230)\end{array}$ & $\begin{array}{c}0.0176^{* * * *} \\
(0.00389)\end{array}$ & $\begin{array}{c}0.0197 * * * \\
(0.00445)\end{array}$ \\
\hline Once/twice week & $\begin{array}{c}0.0703 * * * * \\
(0.0240)\end{array}$ & $\begin{array}{c}-0.00334 * * * \\
(0.00106)\end{array}$ & $\begin{array}{c}-0.00526^{* * * *} \\
(0.00168)\end{array}$ & $\begin{array}{c}-0.00908 * * * * \\
(0.00292)\end{array}$ & $\begin{array}{c}-0.00645^{* * * *} \\
(0.00212)\end{array}$ & $\begin{array}{c}0.0114 * * * \\
(0.00365)\end{array}$ & $\begin{array}{c}0.0127 * * * \\
(0.00413)\end{array}$ \\
\hline $\begin{array}{l}\text { Once/twice month } \\
\text { Frequency of meeting people }\end{array}$ & $\begin{array}{c}0.0267 \\
(0.0241)\end{array}$ & $\begin{array}{l}-0.00116 \\
(0.00110)\end{array}$ & $\begin{array}{c}-0.00184 \\
(0.00174)\end{array}$ & $\begin{array}{c}-0.00318 \\
(0.00303)\end{array}$ & $\begin{array}{c}-0.00226 \\
(0.00220)\end{array}$ & $\begin{array}{c}0.00399 \\
(0.00378)\end{array}$ & $\begin{array}{c}0.00444 \\
(0.00428)\end{array}$ \\
\hline Most days & $\begin{array}{c}0.104 * * * \\
(0.0359)\end{array}$ & $\begin{array}{c}-0.00484 * * * \\
(0.00163)\end{array}$ & $\begin{array}{c}-0.00762 * * * * \\
(0.00257)\end{array}$ & $\begin{array}{c}-0.0131 * * * \\
(0.00445)\end{array}$ & $\begin{array}{c}-0.00927 * * * * \\
(0.00319)\end{array}$ & $\begin{array}{c}0.0165 * * * * \\
(0.00557)\end{array}$ & $\begin{array}{c}0.0183 * * * \\
(0.00625)\end{array}$ \\
\hline Once/twice week & $\begin{array}{c}0.0888 * * \\
(0.0352)\end{array}$ & $\begin{array}{c}-0.00411 * * * * \\
(0.00159)\end{array}$ & $\begin{array}{c}-0.00647 * * \\
(0.00252)\end{array}$ & $\begin{array}{l}-0.0112^{* *} \\
(0.00436)\end{array}$ & $\begin{array}{c}-0.00790^{* * *} \\
(0.00314)\end{array}$ & $\begin{array}{l}0.0140 * * \\
(0.00546)\end{array}$ & $\begin{array}{l}0.0156^{* *} \\
(0.00614)\end{array}$ \\
\hline Once/twice month & $\begin{array}{c}0.0489 \\
(0.0355)\end{array}$ & $\begin{array}{c}-0.00218 \\
(0.00157)\end{array}$ & $\begin{array}{l}-0.00347 \\
(0.00253)\end{array}$ & $\begin{array}{c}-0.00604 \\
(0.00446)\end{array}$ & $\begin{array}{c}-0.00438 \\
(0.00337)\end{array}$ & $\begin{array}{c}0.00754 \\
(0.00548)\end{array}$ & $\begin{array}{c}0.00854 \\
(0.00644)\end{array}$ \\
\hline How often go to the cinema & & & & & & & \\
\hline At least once week/month & $\begin{array}{c}0.0493 * * \\
(0.0241)\end{array}$ & $\begin{array}{c}-0.00225^{* *} \\
(0.00111)\end{array}$ & $\begin{array}{c}-0.00356^{* *} \\
(0.00178)\end{array}$ & $\begin{array}{c}-0.00620 * * \\
(0.00314)\end{array}$ & $\begin{array}{c}-0.00449^{*} \\
(0.00236)\end{array}$ & $\begin{array}{c}0.00774 * * \\
(0.00386)\end{array}$ & $\begin{array}{l}0.00876^{*} \\
(0.00452)\end{array}$ \\
\hline Several times a year & $\begin{array}{c}0.0445 * * * \\
(0.0157)\end{array}$ & $\begin{array}{c}-0.00210^{* * * * *} \\
(0.000779)\end{array}$ & $\begin{array}{c}-0.00331 \text { **** } \\
(0.00124)\end{array}$ & $\begin{array}{c}-0.00573 * * * * \\
(0.00215)\end{array}$ & $\begin{array}{c}-0.00407 * * * * \\
(0.00156)\end{array}$ & $\begin{array}{c}0.00720 * * * \\
(0.00268)\end{array}$ & $\begin{array}{c}0.00801 * * * * \\
(0.00303)\end{array}$ \\
\hline How often go to theatre/concert & & & & & & & \\
\hline At least once week/month & $\begin{array}{c}0.106 * * * \\
(0.0293)\end{array}$ & $\begin{array}{c}-0.00476^{* * * *} \\
(0.00129)\end{array}$ & $\begin{array}{c}-0.00773 * * * * \\
(0.00216)\end{array}$ & $\begin{array}{c}-0.0138 * * * \\
(0.00399)\end{array}$ & $\begin{array}{c}-0.0107 * * * \\
(0.00341)\end{array}$ & $\begin{array}{c}0.0167 * * * * \\
(0.00466)\end{array}$ & $\begin{array}{c}0.0202 * * * \\
(0.00619)\end{array}$ \\
\hline Several times a year & $\begin{array}{c}0.0725 * * * \\
(0.0139)\end{array}$ & $\begin{array}{c}-0.00347 * * * * \\
(0.000705)\end{array}$ & $\begin{array}{c}-0.00549 * * * \\
(0.00113)\end{array}$ & $\begin{array}{c}-0.00954 * * * * \\
(0.00197)\end{array}$ & $\begin{array}{c}-0.00687 * * * * \\
(0.00147)\end{array}$ & $\begin{array}{l}0.0119 * * * \\
(0.00244)\end{array}$ & $\begin{array}{c}0.0134 * * * \\
(0.00283)\end{array}$ \\
\hline How often go out for a drink & & & & & & & \\
\hline At least once week & $\begin{array}{c}0.0950^{* * * *} \\
(0.0246)\end{array}$ & $\begin{array}{c}-0.00440^{* * * *} \\
(0.00113)\end{array}$ & $\begin{array}{c}-0.00700^{* * * *} \\
(0.00181)\end{array}$ & $\begin{array}{c}-0.0122 * * * \\
(0.00319)\end{array}$ & $\begin{array}{c}-0.00885^{* * * *} \\
(0.00242)\end{array}$ & $\begin{array}{c}0.0152 * * * * \\
(0.00391)\end{array}$ & $\begin{array}{c}0.0172 * * * \\
(0.00461)\end{array}$ \\
\hline At least once month & $0.0503 * *$ & $-0.00240 * *$ & $-0.00379 * *$ & $-0.00659 * *$ & $-0.00474 * *$ & $0.00824 * *$ & $0.00928 * *$ \\
\hline
\end{tabular}




\begin{tabular}{lccccccc} 
& $(0.0214)$ & $(0.00101)$ & $(0.00161)$ & $(0.00283)$ & $(0.00211)$ & $(0.00350)$ & $(0.00405)$ \\
Several times a year & 0.00927 & -0.000227 & -0.000356 & -0.000611 & -0.000427 & 0.000773 & 0.000848 \\
& $(0.0188)$ & $(0.000939)$ & $(0.00147)$ & $(0.00254)$ & $(0.00178)$ & $(0.00320)$ & $(0.00353)$ \\
How often attend local groups & & & & & & \\
\cline { 1 - 5 } At least once week & $0.0971^{* * *}$ & $-0.00461^{* * *}$ & $-0.00747 * * *$ & $-0.0133^{* * *}$ & $-0.0102^{* * *}$ & $0.0162^{* * *}$ & $0.0194^{* * * *}$ \\
& $(0.0264)$ & $(0.00116)$ & $(0.00195)$ & $(0.00358)$ & $(0.00302)$ & $(0.00420)$ & $(0.00551)$ \\
At least once month & $0.0374 *$ & -0.00164 & -0.00260 & -0.00452 & -0.00325 & 0.00565 & 0.00636 \\
& $(0.0220)$ & $(0.00109)$ & $(0.00175)$ & $(0.00307)$ & $(0.00228)$ & $(0.00379)$ & $(0.00439)$ \\
Several times a year & 0.0155 & -0.000813 & -0.00128 & -0.00221 & -0.00157 & 0.00278 & 0.00309 \\
& $(0.0213)$ & $(0.00112)$ & $(0.00178)$ & $(0.00308)$ & $(0.00222)$ & $(0.00386)$ & $(0.00434)$ \\
\hline \# of Obs & 50620 & \multicolumn{70}{c}{50620} \\
\hline
\end{tabular}

Standard errors in parentheses; $* * * p<0.01, * * p<0.05, * p<0.1$ 
Table A2: Marginal effects for the random effects generalized ordered probit Mundlak estimations

\begin{tabular}{|c|c|c|c|c|c|c|}
\hline & 1 & 2 & 3 & 4 & 5 & 6 \\
\hline Equiv. Monthly House. Income & $\begin{array}{c}-1.71 \mathrm{e}-06 * * * \\
(3.51 \mathrm{e}-07)\end{array}$ & $\begin{array}{c}-3.59 \mathrm{e}-06 * * * \\
(5.89 \mathrm{e}-07)\end{array}$ & $\begin{array}{c}-9.12 \mathrm{e}-06 * * * \\
(1.14 \mathrm{e}-06)\end{array}$ & $\begin{array}{c}5.13 \mathrm{e}-06^{* * * *} \\
(1.60 \mathrm{e}-06)\end{array}$ & $\begin{array}{c}2.16 \mathrm{e}-05^{* * *} \\
(1.66 \mathrm{e}-06)\end{array}$ & $\begin{array}{c}-1.23 \mathrm{e}-05^{* * * *} \\
(1.18 \mathrm{e}-06)\end{array}$ \\
\hline \multicolumn{7}{|l|}{ Health Problems } \\
\hline Arms, legs, hands, etc & $\begin{array}{c}0.00845^{* * * *} \\
(0.00151)\end{array}$ & $\begin{array}{l}0.00449 * \\
(0.00230)\end{array}$ & $\begin{array}{c}0.0206 * * * \\
(0.00390)\end{array}$ & $\begin{array}{c}0.00259 \\
(0.00505)\end{array}$ & $\begin{array}{c}-0.0332 * * * \\
(0.00519)\end{array}$ & $\begin{array}{l}-0.00299 \\
(0.00382)\end{array}$ \\
\hline Sight & $\begin{array}{l}-0.00142 \\
(0.00213)\end{array}$ & $\begin{array}{c}0.00473 \\
(0.00401)\end{array}$ & $\begin{array}{c}0.00522 \\
(0.00697)\end{array}$ & $\begin{array}{c}-0.0132 \\
(0.00919)\end{array}$ & $\begin{array}{l}-0.00223 \\
(0.00931)\end{array}$ & $\begin{array}{c}0.00689 \\
(0.00699)\end{array}$ \\
\hline Hearing & $\begin{array}{c}0.00750^{* * * *} \\
(0.00252)\end{array}$ & $\begin{array}{c}0.00581 \\
(0.00377)\end{array}$ & $\begin{array}{c}0.00705 \\
(0.00626)\end{array}$ & $\begin{array}{l}0.000657 \\
(0.00774)\end{array}$ & $\begin{array}{l}-0.0141^{*} \\
(0.00803)\end{array}$ & $\begin{array}{l}-0.00688 \\
(0.00604)\end{array}$ \\
\hline Skin conditions/allergy & $\begin{array}{c}-0.00283^{*} \\
(0.00159)\end{array}$ & $\begin{array}{l}0.000802 \\
(0.00286)\end{array}$ & $\begin{array}{l}-0.00289 \\
(0.00486)\end{array}$ & $\begin{array}{c}0.0127 * \\
(0.00663)\end{array}$ & $\begin{array}{c}0.00349 \\
(0.00701)\end{array}$ & $\begin{array}{l}-0.0113 * * \\
(0.00510)\end{array}$ \\
\hline Chest/breathing & $\begin{array}{l}0.00322 * \\
(0.00174)\end{array}$ & $\begin{array}{l}0.00485^{*} \\
(0.00288)\end{array}$ & $\begin{array}{l}0.0100 * * \\
(0.00500)\end{array}$ & $\begin{array}{c}-0.0268 * * * \\
(0.00624)\end{array}$ & $\begin{array}{l}-0.0121^{*} \\
(0.00671)\end{array}$ & $\begin{array}{l}0.0208 * * * \\
(0.00576)\end{array}$ \\
\hline Heart/blood pressure & $\begin{array}{c}0.00540 * * * \\
(0.00181)\end{array}$ & $\begin{array}{c}0.0170 * * * \\
(0.00308)\end{array}$ & $\begin{array}{l}0.000981 \\
(0.00477)\end{array}$ & $\begin{array}{l}-0.000109 \\
(0.00608)\end{array}$ & $\begin{array}{c}-0.0293 * * * \\
(0.00621)\end{array}$ & $\begin{array}{c}0.00611 \\
(0.00484)\end{array}$ \\
\hline Stomach or digestion & $\begin{array}{c}0.00255 \\
(0.00188)\end{array}$ & $\begin{array}{l}0.0120 * * * \\
(0.00340)\end{array}$ & $\begin{array}{c}0.00588 \\
(0.00560)\end{array}$ & $\begin{array}{c}0.0109 \\
(0.00767)\end{array}$ & $\begin{array}{c}-0.0206 * * * \\
(0.00784)\end{array}$ & $\begin{array}{l}-0.0108 * \\
(0.00563)\end{array}$ \\
\hline Diabetes & $\begin{array}{c}0.00125 \\
(0.00347)\end{array}$ & $\begin{array}{c}0.00259 \\
(0.00590)\end{array}$ & $\begin{array}{c}0.000946 \\
(0.0101)\end{array}$ & $\begin{array}{l}-0.00167 \\
(0.0120)\end{array}$ & $\begin{array}{l}-0.0158 \\
(0.0130)\end{array}$ & $\begin{array}{c}0.0127 \\
(0.0118)\end{array}$ \\
\hline Anxiety, depression & $\begin{array}{c}0.0293 * * * \\
(0.00280)\end{array}$ & $\begin{array}{c}0.0489 * * * \\
(0.00414)\end{array}$ & $\begin{array}{c}0.0537 * * * \\
(0.00618)\end{array}$ & $\begin{array}{l}-0.0134^{*} \\
(0.00786)\end{array}$ & $\begin{array}{c}-0.0966 * * * \\
(0.00791)\end{array}$ & $\begin{array}{c}-0.0219 * * * \\
(0.00611)\end{array}$ \\
\hline Migraine & $\begin{array}{l}-2.76 \mathrm{e}-05 \\
(0.00184)\end{array}$ & $\begin{array}{c}0.00943 * * * \\
(0.00343)\end{array}$ & $\begin{array}{l}0.0133^{* *} \\
(0.00579)\end{array}$ & $\begin{array}{c}0.00646 \\
(0.00762)\end{array}$ & $\begin{array}{c}-0.0257 * * * \\
(0.00809)\end{array}$ & $\begin{array}{l}-0.00343 \\
(0.00623)\end{array}$ \\
\hline Other & $\begin{array}{c}0.00713 * * * \\
(0.00259)\end{array}$ & $\begin{array}{c}0.0156^{* * *} \\
(0.00435)\end{array}$ & $\begin{array}{c}0.0271 * * * \\
(0.00721)\end{array}$ & $\begin{array}{c}0.0110 \\
(0.00944)\end{array}$ & $\begin{array}{c}-0.0466 * * * \\
(0.00922)\end{array}$ & $\begin{array}{l}-0.0143^{* *} \\
(0.00647)\end{array}$ \\
\hline \multicolumn{7}{|l|}{ Marital Status } \\
\hline Separated & $\begin{array}{c}0.0234 * * * \\
(0.00546)\end{array}$ & $\begin{array}{c}0.0354 * * * \\
(0.00802)\end{array}$ & $\begin{array}{c}0.0556^{* * * *} \\
(0.0121)\end{array}$ & $\begin{array}{l}-0.00571 \\
(0.0148)\end{array}$ & $\begin{array}{c}-0.0839 * * * \\
(0.0143)\end{array}$ & $\begin{array}{c}-0.0248 * * \\
(0.0102)\end{array}$ \\
\hline Divorced & $\begin{array}{c}0.0168 * * * \\
(0.00289)\end{array}$ & $\begin{array}{l}0.0201 * * * \\
(0.00408)\end{array}$ & $\begin{array}{c}0.0407 * * * \\
(0.00650)\end{array}$ & $\begin{array}{l}-0.00895 \\
(0.00792)\end{array}$ & $\begin{array}{c}-0.0539 * * * \\
(0.00815)\end{array}$ & $\begin{array}{l}-0.0148 * * \\
(0.00590)\end{array}$ \\
\hline Widowed & $\begin{array}{c}0.0305 * * * \\
(0.00444)\end{array}$ & $\begin{array}{c}0.0274 * * * \\
(0.00536)\end{array}$ & $\begin{array}{c}0.0678 * * * \\
(0.00810)\end{array}$ & $\begin{array}{c}-0.0134 \\
(0.00829)\end{array}$ & $\begin{array}{c}-0.0903 * * * \\
(0.00815)\end{array}$ & $\begin{array}{c}-0.0220 * * * \\
(0.00572)\end{array}$ \\
\hline Never married & $\begin{array}{c}0.0112 * * * * \\
(0.00205)\end{array}$ & $\begin{array}{c}0.0190 * * * \\
(0.00311)\end{array}$ & $\begin{array}{c}0.0394 * * * \\
(0.00496)\end{array}$ & $\begin{array}{l}0.000608 \\
(0.00586)\end{array}$ & $\begin{array}{c}-0.0504 * * * \\
(0.00637)\end{array}$ & $\begin{array}{c}-0.0198 * * * \\
(0.00477)\end{array}$ \\
\hline \multicolumn{7}{|l|}{ Frequency of talking to neighbors } \\
\hline Most days & $\begin{array}{c}-0.00691 * * * \\
(0.00185)\end{array}$ & $\begin{array}{c}-0.0103 * * * \\
(0.00320)\end{array}$ & $\begin{array}{l}-0.00945 \\
(0.00576)\end{array}$ & $\begin{array}{c}-0.00830 \\
(0.00814)\end{array}$ & $\begin{array}{c}0.0305 * * * \\
(0.00841)\end{array}$ & $\begin{array}{c}0.00444 \\
(0.00635)\end{array}$ \\
\hline Once/twice week & $\begin{array}{c}-0.00966 * * * \\
(0.00176)\end{array}$ & $\begin{array}{c}-0.0103 * * * \\
(0.00310)\end{array}$ & $\begin{array}{l}-0.00824 \\
(0.00559)\end{array}$ & $\begin{array}{c}0.00841 \\
(0.00804)\end{array}$ & $\begin{array}{c}0.0364 * * * \\
(0.00830)\end{array}$ & $\begin{array}{c}-0.0166 * * * \\
(0.00605)\end{array}$ \\
\hline Once/twice month & $\begin{array}{c}-0.00839 * * * \\
(0.00165)\end{array}$ & $\begin{array}{c}-0.00615^{*} \\
(0.00328)\end{array}$ & $\begin{array}{c}0.00394 \\
(0.00620)\end{array}$ & $\begin{array}{c}0.00723 \\
(0.00902)\end{array}$ & $\begin{array}{c}0.0275^{* * *} \\
(0.00925)\end{array}$ & $\begin{array}{c}-0.0242 * * * \\
(0.00620)\end{array}$ \\
\hline \multicolumn{7}{|l|}{ Frequency of meeting people } \\
\hline Most days & $\begin{array}{c}-0.00443 \\
(0.00273)\end{array}$ & $\begin{array}{c}-0.0140 * * * \\
(0.00479)\end{array}$ & $\begin{array}{l}-0.00479 \\
(0.00864)\end{array}$ & $\begin{array}{c}-0.00320 \\
(0.0125)\end{array}$ & $\begin{array}{c}0.0208 \\
(0.0129)\end{array}$ & $\begin{array}{c}0.00566 \\
(0.00939)\end{array}$ \\
\hline Once/twice week & $\begin{array}{c}-0.00697 * * * * \\
(0.00265)\end{array}$ & $\begin{array}{c}-0.0135 * * * \\
(0.00469)\end{array}$ & $\begin{array}{l}-0.00537 \\
(0.00853)\end{array}$ & $\begin{array}{l}0.00678 \\
(0.0124)\end{array}$ & $\begin{array}{l}0.0226^{*} \\
(0.0128)\end{array}$ & $\begin{array}{l}-0.00347 \\
(0.00926)\end{array}$ \\
\hline Once/twice month & $\begin{array}{c}-0.00583 * * \\
(0.00247)\end{array}$ & $\begin{array}{c}-0.00913 * * \\
(0.00462)\end{array}$ & $\begin{array}{l}0.000708 \\
(0.00901)\end{array}$ & $\begin{array}{l}0.00996 \\
(0.0133)\end{array}$ & $\begin{array}{c}0.0142 \\
(0.0136)\end{array}$ & $\begin{array}{l}-0.00992 \\
(0.00942)\end{array}$ \\
\hline \multicolumn{7}{|l|}{ How often go to the cinema } \\
\hline At least once week/month & $\begin{array}{l}-0.00256 \\
(0.00192)\end{array}$ & $\begin{array}{c}-0.0104 * * * \\
(0.00300)\end{array}$ & $\begin{array}{c}-0.0217 * * * \\
(0.00522)\end{array}$ & $\begin{array}{l}0.0150 * * \\
(0.00727)\end{array}$ & $\begin{array}{c}0.0392 * * * \\
(0.00782)\end{array}$ & $\begin{array}{c}-0.0196 * * * \\
(0.00553)\end{array}$ \\
\hline Several times a year & $\begin{array}{c}-0.00832 * * * \\
(0.00137)\end{array}$ & $\begin{array}{c}-0.0102 * * * * \\
(0.00230)\end{array}$ & $\begin{array}{c}-0.0208 * * * \\
(0.00392)\end{array}$ & $\begin{array}{c}0.0274 * * * \\
(0.00536)\end{array}$ & $\begin{array}{c}0.0413^{* * *} \\
(0.00566)\end{array}$ & $\begin{array}{c}-0.0295 * * * \\
(0.00398)\end{array}$ \\
\hline How often go to theatre/concert & & & & & & \\
\hline At least once week/month & $\begin{array}{c}-0.00385 \\
(0.00261)\end{array}$ & $\begin{array}{c}-0.0128 * * * \\
(0.00410)\end{array}$ & $\begin{array}{c}-0.0165^{* *} \\
(0.00746)\end{array}$ & $\begin{array}{l}-0.0146 \\
(0.0102)\end{array}$ & $\begin{array}{c}0.0486 * * * \\
(0.0108)\end{array}$ & $\begin{array}{l}-0.000965 \\
(0.00776)\end{array}$ \\
\hline Several times a year & $\begin{array}{c}-0.00922^{* * * *} \\
(0.00135)\end{array}$ & $\begin{array}{c}-0.00947 * * * * \\
(0.00226)\end{array}$ & $\begin{array}{c}-0.0158 * * * \\
(0.00375)\end{array}$ & $\begin{array}{l}0.0105^{* *} \\
(0.00504)\end{array}$ & $\begin{array}{c}0.0313 * * * \\
(0.00526)\end{array}$ & $\begin{array}{l}-0.00735^{*} \\
(0.00379)\end{array}$ \\
\hline How often go out for a drink & & & & & & \\
\hline At least once week & $\begin{array}{c}-0.0124 * * * \\
(0.00150)\end{array}$ & $\begin{array}{c}-0.0170 * * * \\
(0.00264)\end{array}$ & $\begin{array}{c}-0.0210 * * * \\
(0.00486)\end{array}$ & $\begin{array}{c}0.0448 * * * \\
(0.00632)\end{array}$ & $\begin{array}{l}0.0136 * * \\
(0.00677)\end{array}$ & $\begin{array}{l}-0.00795 \\
(0.00531)\end{array}$ \\
\hline At least once month & $\begin{array}{c}-0.0113 * * * \\
(0.00140)\end{array}$ & $\begin{array}{c}-0.0114 * * * \\
(0.00262)\end{array}$ & $\begin{array}{c}-0.0130 * * * \\
(0.00481)\end{array}$ & $\begin{array}{c}0.0370 * * * \\
(0.00652)\end{array}$ & $\begin{array}{l}0.0160 * * \\
(0.00692)\end{array}$ & $\begin{array}{c}-0.0174 * * * \\
(0.00491)\end{array}$ \\
\hline Several times a year & $\begin{array}{c}-0.0103 * * * \\
(0.00132)\end{array}$ & $\begin{array}{c}-0.00949 * * * \\
(0.00252)\end{array}$ & $\begin{array}{l}-0.00490 \\
(0.00468)\end{array}$ & $\begin{array}{c}0.0353 * * * \\
(0.00641)\end{array}$ & $\begin{array}{c}0.0245 * * * \\
(0.00678)\end{array}$ & $\begin{array}{c}-0.0350 * * * \\
(0.00434)\end{array}$ \\
\hline
\end{tabular}




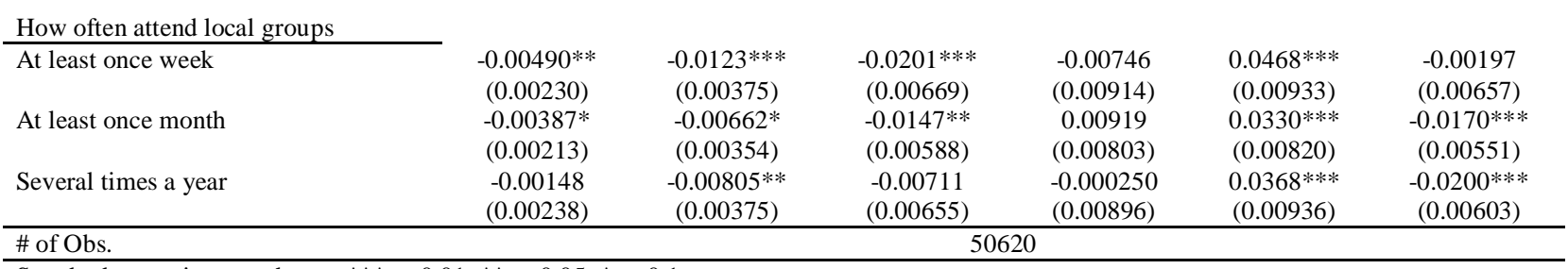

Standard errors in parentheses; $* * * p<0.01, * * p<0.05, * p<0.1$ 